\title{
Appraising Work-Based Learning Experiences of Technical and Vocational (Teacher) Educationand Training (TVTET) Programmes In Nigeria
}

\author{
Ugochukwu P.N. Amadi \\ Federal College of Education (Technical), Umunze-Nigeria
}

\section{Doi:10.5901/mjss.2013.v4n5p137}

\begin{abstract}
The skill emphasis in the implementation of technical and vocational education and training (TVET) programmes demands that conscious and concerted effort are made to put in place strategies that would guarantee hand on learning experiences. Basically, a sure way of realizing these critical objectives is by the instrument of workbased learning (WBL) which implies the establishment of a synergistic relationship between TVET institution, business and industry as well as community - based resources inventory. This study has attempted to appraise the extent to which this synergy has worked in the Nigeria TVET system, using the seven (7) Federal Colleges of Education (Technical) in the South-Eastern geo-political zone of the country as study area. A total of 200 TVET instructors served as study sample while a structured questionnaire was used in generating data relevant to the study. Data analysis was based on the statistical tools of frequency, mean and percentage. Findings indicated among other things that, all emphasis so far is on the Student Industrial Work Experience Scheme (SIWES) leaving other avenues or strategies almost unexploited. Such other strategies identified by the study included: cooperative work experience Programme, job shadowing, clinical work experience, youth apprenticeship programme, school-based enterprises, internships, to list a few. Factors responsible for this anomalous situation were indicated to include poor policy frame-work, curricular defects, and inexperience on the part of administrators of TVET programmes. Recommended important strategies emphasized awareness creation through government-industry forum, curriculum restructuring and regular retraining of TVET instructors and teacher -trainers.
\end{abstract}

\section{Introduction}

Technical and Vocational Education and Training (TVET) is a programme designed to equip the youth with skills, knowledge and habit cultures that would enable them to secure and hold job successfully. However, the unabated increase in youth unemployment rate in Nigeria poses a huge burden of conscience on the quality of (TVET) programme being delivered at moment. This state of affairs demands that extra efforts be made in the non-traditional dimensions (i.e. schooling) to ensure that graduates of (TVET) programmes become job creators and employers of labour, rather than job seekers. The introduction of entrepreneurship studies into the school curriculum is a welcome development meant to address the lapse at regrettably; the expected improvement prospects have continued to be more of an illusion than reality (Amadi, 2006 \& Aghanta 1982).

Entrepreneurship here is premised on the belief that (TVET) graduates have been exposed to all avenues that would ensure acquisition of the right skills of the respective vocations or occupational challenge including but not limited to psycho-production, manipulative, attitudinal, cognitive and of course, entrepreneurship. (Zahrandeen, 1990). Learners can acquire these skills only in proportion as they were exposed to the right learning environments and experiences through such process and strategies that guarantee hands-on learning experience. This believed to be possible with the introduction of learners to work-learn situations that only appropriate and suitable work-based learning programmes could guarantee. 


\section{Concept of Work-Based Learning}

WBL can be defined as an institutional arrangement in which learners are concurrently exposed to both work and learning environments (scorecardforskills.com2011). WBL literally is an attempt to expand the walls of classroom to include the community as a learning resource. It therefore, extends the frontiers of the classroom to the work-world (National centre on secondary education and training (NCSET), 2011). WBL affords learners ample opportunities to learn a variety of skills that guarantee synergistic relationship between the school and the world-of-work. It is an attempt to narrow the gap existing between theory and practice thereby, making meaningful learning possible. Okon (2011) defines WBL as experiential learning programmes that use the work environment as an important component of the curriculum. Through WBL, structured learning experiences are provided to the learners through the collaborative efforts of employers of labour and the school. This arrangement avails learners opportunities to acquire a variety of skills upon exposure to rigorous academic engagements simultaneously with hands-on career development experiences. WBL forges a formidable link between classroom instruction, the world of work and failure career opportunities, as neither school-based learning nor involvement of a learner in professional work alone (i.e. apprenticeship) guarantees the occurrence of appropriate learning to the extent of satisfying the qualification requirements of the work-world (Jarrad \& Jefsioutine, 2006). As reported by Schrenko (2011), what could be taken as curriculum standard is a recommendation by the University of the State of Georgia, United States of America that 'a work-based learning programme must include work experience opportunities, job training and work experiences coordinated with both academic and occupational learning in school-based programmes that are relevant to students' programme of study. In this regard, instruction and activities in academic and occupational work-place competencies, positive work attitudes, employable practical skills, instructions in all aspects of industry -business decision, planning, management, financing, labour matters, community issues as well as health, safety and environment must be given a place of prominence (Institute of Community Integration (ICl, 2011).

\section{Rationale for Work-Based Learning Experiences in TVET}

Suffice to state that WBL offers students the critical opportunity for experience how a classroom instruction connects to the work-world and future career prospects as well as job opportunities. In specific terms WBL makes it possible for active collaborative participation of students, educators, employers, parents and appropriate agencies and community representations; development of learning and work-place competencies, motivation of students to stay in school, improvement of students' performance, improvement of graduate employability, increased awareness of non-traditional career opportunities as well as students ability to identify career pathways.

\section{Forms of Work-Based Learning Programmes in TVET}

Although WBL programmes are presented in a variety of ways, they aim at the common goal of providing learners with experiential exposure is the work-world as to guaranteeing eventual smooth transition to the world-of-work upon graduation. Some of the WBL programmes relevant to TVET include industrial training, field trips, excursion, job shadowing, school-based enterprises and school entrepreneurial ventures, internship/practicum, clinical work experiences, cooperative work experiences, youth apprenticeship career fours guest and career days (Orji, 1996 \& Schrenko, 2010).

Notably, each of these WBL experiences has its own mode of operation in that respect therefore, allowance for work-based experience may be for hours, days or weeks as the case may be. In whatever form WBL is provided to the learners, it needs to be emphasized that such learning experiences must follow a progressive path that can be initiated at early schooling and continue through secondary to post-secondary 
levels. WBL programmes vary in the way they are structured and operated as well as in their intensity and duration, and for the purpose of their study, a brief explanation of each programnme would be presented as follows:

Field trips are generally exploratory strategy that offers career awareness to learners at their very formative stage. Specifically, planned field trips to industries and the business avail the students enough opportunities to explore different work places (Aghenta, 1991).

Career exploration is a component of WBL that exposes learners to a variety of work settings to assist them in making decisions about future career directions and occupations. It involves examination of interests, values, beliefs and strengths in relation to the demands and other characteristics of work environment (Schrenko, 2011).

Cooperative work experience programme consists of an arrangement between the school and employers that make use of work-place and its environment to create links between learning in school and skills required in the work place (Orji, 1996).

Youth Apprenticeship Programme (YAP) is a school-to-work initiative designed to afford learners the opportunity to be simultaneously engaged in both school-based and work-based exposures. And while the school-based is a highly structured curriculum integrating both academic and occupational experiences, the work-place component offers the learners paid on-the-job intensive training experiences that are relevant to the curriculum offering. This feature conforms to the theory of vocational education which states that "effective learning and skill acquisition in vocational education is only possible if training takes place in the work-place or its replica (Agusibo, 1984 and Amadi, Orikpe \& Osinem, 2007).

Internship, also known as practicum is a one-time, short-term placement of learners in a students' programme of study. It is designed to ensure intensive observation of how the intern performs tasks on specific job areas (Schrenko, 2011).

School-based Entrepreneurial Ventures are designed to encourage students to produce goods and services as part of their educational programme of study, thereby assisting learners to develop competencies requisite to ownership and management of business outfits. Under this structure, students plan, implement programmes, conduct feasibility studies, evaluate business operations including marketing services.

Job shadowing implies a student keenly observing and modeling one employee or worker as a workplace for one or more days to learn a particular occupation or industry. This enables learners to refine their career objectives, select a career focus area for the latter part of high school and participate in a more advanced level of WBL (Johnson, Sword \& Habbeger, 2008).

In summary, work-based learning strategies or packages relevant in our present system of education are available that if properly put into effective use are capable of encouraging acquisition of hands-on skills by learners.

\section{Purpose of the Study}

The general purpose of this study is to establish the extent to which schools that run TVET teacher programmes explore and the engagement of work-based strategies in teaching their students. The following specific objectives were addressed:

1. To determine level of TVET teacher trainers' awareness of the existence of the different forms of WBL programmes.

2. Find out the WBL programmes TVET teacher trainers and institutions engage students in their course of training.

3. To ascertain the opinion of TVET teacher trainers on the attendant benefits of WBL programmes to students, school, industry and society at large. 
4. To determine the constraints to effective integration of WBL experiences into TVET teacher programmes.

5. To determine strategies for mitigating the constraints to effective WBL-TVET integration into teacher education programmes.

\section{Research Questions}

1. What is the level of TVET teacher trainers' awareness of the existence of different forms of WBL programme as a component of TVET teacher programme?

2. What are the WBL programmes that your students are engaged in during their study?

3. What benefits could derive from WBL-TVET integration into teacher education programme?

4. What constraints militate against effective WBL-TVET integration?

5. What are the strategies that can be used to mitigate the constraints to effective WBL-TVET integration into teacher education programme?

\section{Methodology}

The study was designed as survey aimed at determining the opinions of TVET teacher educators on the problem under investigation. All TVET teacher trainers in the seven (7) Federal Colleges of Education (Technical) in the 3 southern geo-political zones namely South-East, South-South and South-West numbering 1122 (National Commission for Colleges of Education NCCE, 2011) was the target population studied. A total of 200 TVET teacher trainers were randomly selected (with a minimum of 28 from each college) to constitute the study sample. A structured questionnaire was used for data collection and with a coefficient of 0.72 on Cronbach alpha scale the instrument was considered reliable enough for the study. Generated data were analyzed using frequency, percentage and mean. Decision point was established at 3.50 such that any item with mean response of 3.50 and above was accepted while any item with mean below 3.50 was not accepted. On percentage basis, items with response of $50 \%$ and above was accepted as high enough.

\section{Presentation of Results}

\section{Research Question 1:}

What is the extent of TVET teacher trainers' awareness of the existence of different the forms of WBL programmes as components of TVET teacher education programmes?

Table 1: Frequencies and percentage awareness of TVET teacher trainerss of the existence of WBL components of TVET programmes.

Response $\mathrm{n}=\mathbf{2 0 0}$

\begin{tabular}{|c|l|c|c|}
\hline S/N & Item Description & Aware (\%) & Not Aware (\%) \\
\hline 1 & Cooperative work experience programme & $198(99)$ & $2(1)$ \\
\hline 2 & Field trips & $900(100)$ & $185(92.5)$ \\
\hline 3 & Job shadowing & $15(7.5)$ & $185(92.5)$ \\
\hline 4 & School-based enterprises & $20(10)$ & $180(90)$ \\
\hline 5 & Entrepreneurial ventures & $20(10)$ & $180(90)$ \\
\hline 6 & Internship/practicum & $168(84)$ & $32(16)$ \\
\hline
\end{tabular}




\begin{tabular}{|c|l|c|c|}
\hline 7 & Clinical experience & $24(12)$ & $176(88)$ \\
\hline 8 & Cooperative education & $24(12)$ & $176(88)$ \\
\hline 9 & Youth apprenticeship & $29(4.5)$ & $171(85.5)$ \\
\hline 10 & Excursions & $200(100)$ & - \\
\hline 11 & SIWES & $200(100)$ & - \\
\hline & Grand Mean $\overline{(\mathbf{X})}$ & $\mathbf{( 1 9 . 2 0 )}$ & $\mathbf{( 8 0 . 8 0 )}$ \\
\hline
\end{tabular}

Results in Table 1 shows that with a Grand mean of 19.20\% the number of TVET teacher trainers who are aware is less than those that are not aware (80.80\%) of the existence of some of the WBL programmes of TVET.

\section{Research Question 2:}

What are the forms of WBL Programmes you/your College engage(s) your students in?

Table 2: Frequency and Mean Responses of TVET Teacher trainers on Utilization of WBL Resources.

Response $\mathbf{n}=\mathbf{2 0 0}$
\begin{tabular}{|c|l|c|c|}
\hline S/N & Item Description & Used (\%) & Not Used (\%) \\
\hline 1 & Cooperative work experience & - & $200(100)$ \\
\hline 2 & Field trips & $190(95)$ & $10(5)$ \\
\hline 3 & Job shadowing & - & $200(100)$ \\
\hline 4 & School-based enterprises & $22(15)$ & $78(85)$ \\
\hline 5 & Entrepreneurial ventures & $22(15)$ & $178(85)$ \\
\hline 6 & Internship/practicum & - & $200(100)$ \\
\hline 7 & Clinical work experience & - & $200(100)$ \\
\hline 8 & Cooperative education & - & $200(100)$ \\
\hline 9 & Youth apprenticeship & $200(100)$ & $174(87)$ \\
\hline 10 & Excursions & $200(100)$ & - \\
\hline 11 & SIWES & $121(60.5)$ & $79(39.5)$ \\
\hline 12 & Career fairs & $82(41)$ & $118(59)$ \\
\hline 13 & Guest speakers & $33.8 \%$ & 66.22 \\
\hline & Grand Mean $\overline{(X)}$ & & \\
\hline
\end{tabular}

Results in the Table 2 indicate that only field trips, excursions, SIWES and career fairs with rating of $50 \%$ and above were engaged in by TVET teacher trainers/institutions.

\section{Research Question 3:}

What are the possible Benefits Derivable from the Integration of WBL Strategies into TVET Teacher Education Programmes? 
Table 3: Frequency and Mean Responses of TVET Teacher trainers on the Benefits of Integration of WBL into TVET Teacher Education Programme.

\begin{tabular}{|c|c|c|c|c|}
\hline $\mathrm{S} / \mathrm{N}$ & Item Description & $(X)$ & SD & Remark \\
\hline 1 & Expose students to adult role-models & 3.64 & .81 & Accept \\
\hline 2 & Applying classroom learning & 3.97 & .82 & Accept \\
\hline 3 & Exploring career options & 3.97 & .82 & Accept \\
\hline 4 & Exploring students to state-of-the-art practices and technology & 3.57 & .52 & Accept \\
\hline 5 & Improving scholastic student workplace motivation & 3.55 & .51 & Accept \\
\hline 6 & Helping students understand workplace expectations & 3.79 & .81 & Accept \\
\hline 7 & Improving post secondary career prospects & 3.72 & .52 & Accept \\
\hline 8 & Helping students make better decisions and plans & 3.50 & .48 & Accept \\
\hline 9 & $\begin{array}{l}\text { Allows students to observe the work world so as to develop workplace } \\
\text { skills }\end{array}$ & 3.72 & .59 & Accept \\
\hline 10 & $\begin{array}{l}\text { Allows students to learn work terminology, work environment and } \\
\text { business and industry protocol. }\end{array}$ & 2.72 & .72 & Accept \\
\hline \multirow[t]{2}{*}{11} & Targeting experiences to a students programme of study. & 3.71 & .60 & Accept \\
\hline & Benefit to Employer & & & \\
\hline 12 & Offering a source of skilled and motivated future employees & 3.77 & .53 & Accept \\
\hline 13 & Increase student retention & 3.84 & .86 & Accept \\
\hline 14 & Provide opportunity for individualized instruction & 3.66 & .57 & Accept \\
\hline \multirow[t]{2}{*}{15} & $\begin{array}{l}\text { Keeping academic and occupational circular up-to-date through regular } \\
\text { integration between school and industry. }\end{array}$ & 5.50 & .49 & Accept \\
\hline & Benefits of Local Community & & & \\
\hline 16 & Enhances awareness of local employment opportunities & 3.72 & .48 & Accept \\
\hline 17 & Enhances improved endogenous/local development & 3.69 & .38 & Accept \\
\hline 18 & $\begin{array}{l}\text { Ensures cooperation and understanding between education, } \\
\text { barriers/industry and community }\end{array}$ & 3.25 & .49 & Accept \\
\hline \multirow[t]{2}{*}{19} & Provides informed, component and productive future workforce. & 3.83 & .68 & Accept \\
\hline & Grand Mean $(X)$ & $3.67 \%$ & 0.60 & Accept \\
\hline
\end{tabular}

The results in Table 3 above show that with a mean range of 3.5 to 4.25 all TVET teachers agreed that each of the items is a potential benefit of the incorporation of work-based learning experiences into TVET programmes.

\section{Research Question 4:}

What Problems and/or Constraints Militate against Effective Integration of Work-Based Learning into TVET Programmes of Colleges of Education. 
Table 4: Frequency and Mean Responses of TVET Teachers on Problems and/or Constraints that Militate against Effective Integration of WBL into TVET Programmes of Colleges of Education.

\begin{tabular}{|c|c|c|c|c|}
\hline $\mathrm{S} / \mathrm{N}$ & Item Description & $\mathrm{X}$ & SD & Remark \\
\hline 1 & $\begin{array}{l}\text { Most identified WBL forms are presently not integrated into NCCE TVET } \\
\text { minimum standard curriculum. }\end{array}$ & 3.66 & .52 & Accept \\
\hline 2 & Nigeria National Policy on Education Places little or emphasis on WBL & 3.90 & .61 & Accept \\
\hline 3 & $\begin{array}{l}\text { Presently only SIWES field trips, excursion and practicum (teaching fraction) } \\
\text { are recommended by NCCE. }\end{array}$ & 3.77 & .42 & Accept \\
\hline 4 & $\begin{array}{l}\text { Industrial and employers of labour are scarcely well informed on their role in } \\
\text { TVET curriculum implementation }\end{array}$ & 3.69 & .57 & Accept \\
\hline 5 & $\begin{array}{l}\text { Industries and business are not fully aware of attendant benefits of WBL to } \\
\text { the work-world }\end{array}$ & 3.44 & .38 & Reject \\
\hline 6 & $\begin{array}{l}\text { Institutions are poorly funded to cope with cost of engaging in other WBL } \\
\text { Programmes }\end{array}$ & 3.67 & .41 & Reject \\
\hline 7 & $\begin{array}{l}\text { Most TVET institutions and instructors lack orientation requisite of effective } \\
\text { harness of WBL }\end{array}$ & 3.06 & .55 & Reject \\
\hline 8 & Non chelae of work-site supervisors & 3.60 & .49 & Accept \\
\hline 9 & Non chalet attitude of school-based supervisors & 3.60 & .49 & Accept \\
\hline 10 & Poor collaborative relationship between work world and schools. & 3.57 & .47 & Accept \\
\hline 11 & $\begin{array}{l}\text { Low level awareness of need to synergize between TVET instructions, Local } \\
\text { Community and industry. }\end{array}$ & 3.99 & .57 & Accept \\
\hline 12 & TVET instructors poor access to relevant WBL programme windows & 3.16 & .39 & Reject \\
\hline & Grand Mean $\overline{(X)}$ & $\begin{array}{c}3.60 \\
\%\end{array}$ & 0.48 & Accept \\
\hline
\end{tabular}

Information in Table 4 above indicate that with the exception of items 5,7 and 12 all others with mean responses ranging from 3.57 to 3.99 were accepted as problems and/or constraints militating against effective integration of WBL experiences into TVET programmes.

\section{Research Question 5:}

What Measures can be used to ensure Effective Integration of WBL Experiences into TVET Teacher Education Programme of Colleges of Education.

Table 5: Frequency and Mean Responses of TVET Teachers on Measures for Effective Integration of WBL Experiences into TVET Programmes of Colleges of Education.

Response $\mathrm{n}=\mathbf{2 0 0}$
\begin{tabular}{|c|l|c|c|c|}
\hline S/N & Item Description & X & SD & Remark \\
\hline 1 & $\begin{array}{l}\text { Nigeria National Policy on Education should be revised to reflect } \\
\text { flexibility in world standards TVET. }\end{array}$ & 4.25 & .52 & Accept \\
\hline 2 & $\begin{array}{l}\text { The NCCE curriculum standards in TVET programmes should be } \\
\text { revised in line with the revised National Education Policy to } \\
\text { accommodate more WBL experiences. }\end{array}$ & 3.82 & .60 & Accept \\
\hline 3 & $\begin{array}{l}\text { TVET teachers should be encouraged to undertake professional } \\
\text { courses bordering in WBL experiences }\end{array}$ & 3.71 & .51 & Accept \\
\hline 4 & TVET institutions should form synergies with industries, business and & 3.67 & .48 & Accept \\
\hline
\end{tabular}




\begin{tabular}{|c|l|c|c|c|}
\hline & local community. & & & \\
\hline 5 & $\begin{array}{l}\text { WBL experiences should be incorporated into TVET Programmes at the } \\
\text { secondary school level. }\end{array}$ & 3.59 & .57 & Accept \\
\hline 6 & $\begin{array}{l}\text { TVET teachers in secondary schools should be encouraged to be } \\
\text { professionally upgraded }\end{array}$ & 3.66 & .49 & Accept \\
\hline 7 & $\begin{array}{l}\text { In-house work shops, talk shops or conferences and seminars on WBL } \\
\text { should be organized regularly for TVET teachers. }\end{array}$ & 3.61 & .66 & Accept \\
\hline 8 & $\begin{array}{l}\text { The industry business world should be encouraged to apprentice the } \\
\text { WBL benefits and therefore be willing to collaborate with TVET } \\
\text { institutions. }\end{array}$ & 3.72 & .56 & Accept \\
\hline 9 & $\begin{array}{l}\text { School-based WBL supervisors should be properly paid for their } \\
\text { services while supervising students on WBL placement. }\end{array}$ & 3.51 & .48 & Accept \\
\hline 10 & $\begin{array}{l}\text { WBL placement officers/coordinators should be very knowledgeable and } \\
\text { experienced in various WBL experiences. }\end{array}$ & 3.61 & .41 & Accept \\
\hline 11 & $\begin{array}{l}\text { School-Based Coordinators officers should be well equipped with } \\
\text { access to e-library resources. }\end{array}$ & 3.76 & .51 & Accept \\
\hline 12 & $\begin{array}{l}\text { School-based WBL supervisors found wanting in the discharge of their } \\
\text { duty should be sanctioned appropriately. }\end{array}$ & 3.55 & .49 & Accept \\
\hline & \begin{tabular}{l} 
Grand Mean $(\mathbf{X})$ \\
\hline
\end{tabular} & 3.71 & $\mathbf{0 . 5 2}$ & Accept \\
\hline
\end{tabular}

Results on the Table 5 show that all the items with mean responses ranging from 3.51 to 4.25 and a Grand Mean $(X)$ of 3.71 were acknowledged by TVET teacher trainerss as potential measures for effective integration of WBL experiences into TVET programmes.

\section{Summary of Major Findings}

Based on analysis of data collected for the study the following major findings were made:

1. Only $19.22 \%$ TVET teacher trainers are aware of existence of different forms of Work-Based learning experience while $80.82 \%$ are not aware.

2. Excursion, field trips, cooperative work experience scheme, practicum and SIWES are the only form of WBL experience TVET teacher trainers are generally aware of.

3. TVET teacher trainers and institutions engage their students in only four major WBL experiences notably, excursion, field trips, SIWES and intership/practicum.

Derivable benefits of WBL-TVET Synergy include:

4. Exposing students to wide range of career opportunities for exploration.

5. Helping students to understand workplace expectations-skills habit and knowledge.

6. Putting classroom theory into practice.

7. Entrepreneurship development in students

8. Keeping academic and occupational curricula in tune with contemporary demands of the work world.

The following were identified as major problems militating against effective WBL-TVET Programmes integration:

9. Defective National Education Policies

10. Defective NCCE Minimum Curriculum Standard

11. Poor orientation of school-based and work-site placement officers and supervisors on strategies for improving TVET-WBL integration, the following were indicated.

12. Revision of the National Education Policy, NCCE Minimum Curriculum standards and secondary education to incorporate substantial work-based learning experiences. 
13. Regular professional development of TVET teachers through seminars, workshops, short-service course and higher studies.

14. Awareness creation for employers, industrial and business on the potential benefits of their collaboration in provision of work-based learning opportunities.

\section{Discussion}

As indicated in the results of data analysis out of the total number TVET teacher trainers only 19.2\% indicated awareness of the existence of different forms of wok-based learning while $80.85 \%$ were unaware. In addition, only a few (mostly traditional ones) are in use namely; Student Industrial Work Experience Scheme (SIWES), Field- trips, Excursions and in- school laboratory, field and workshop practical.The above situation cannot make effective skill acquisition by students. This agrees with the views of Uzoagulu (2010), Ajayi (1991) \& Bridges (1993) that skills are developed when training operating are carried out in a work environment and with the right tools.

Building a synergy between the school, and industry/ business through work-based learning contacts were seen to have great potential benefits to the student, the school, the industry and the society at large. When students are aided with hands-on learning experiences, habit formation and skill acquisition are made more effective (Eccelestone 1997). There will be greater productivity of the industry and business, the economy as well stands to gain immensely as the school would have succeeded in justifying her expenditure on her programmes (Agbemu, 2007).

The failure of the Nigeria's College of Education system in implementing a reliable WBL-TVET synergy has been attributed among other factors to educational policies and curricula that are deficient in prescribing these modes of skills teaching and training (Holmes, 1995). But considering that what the curriculum prescribes in the minimum standard or bench mark schools and TVET teachers are encouraged to explore more opportunities when they are able to identify such other avenues and are not constrained by any policy frame work. Again most employers tend to shy away from accepting and placing students on Industrial Training obvious of the benefits they stand to gain at the long run. Poor supervision of work experiences by both work-site coordinators and school-based supervisors was highly indicated as a major constraint and this confirms the earlier finding of Agbai (1992) \& Johnson et al (2004) who blamed the poor skills development during SIWES programme on poor supervision by (and poor mobilization of the ) school supervisors.

\section{Conclusion}

Forming an effective synergy between the work-world and the school through work-based learning contacts can be improved upon by first reviewing the National Education Policy and curricula to embody the WBL component. It is believed that this is the first successful step to be taken in improving the situation, and it has to take cognizance of the secondary level of education which is a critical stage in the career development of the child.

\section{Recommendations}

1. Restructuring of the TVET curriculum for teacher education to accommodate WBL experiences that have succeeded in other climes.

2. Training and retraining of TVET teacher trainers through regular attendance at workshops, seminars and conferences and free access to virtual resources should be employed.

3. Funding of TVET teacher education programmes should be improved substantial through partnership with employers of labour, and the business. 
4. Awareness creation through government-industry forum should be instituted considering that most employers presently do not appreciate the importance of such a synergistic relationship.

\section{References}

Agbai, J.O. (1992). Toward Optimizing the Benefits of the Supervised Industrial Work Experience Scheme (SIWES) in Vocational Teacher Education. In Anyakoha, E.U. \& Osuala E.C. (eds.) Vocational/Technical Education for SelfReliance. Journal of the Nigerian Vocational Association 2 (1).

Agbemu, T.P. (2007). Youth Perception of Empowerment through Skills Development and Entrepreneurship. Book of Readings Association for Business Educators in Nigeria (ABEN) 1 (7).

Aghenta, F. (1982). Usefulness of Field-Trips and Excursion to Students. The Daily Sketch Newspaper, January 1, p.3.

Agusiobo, O.O. (1984). Introduction to Vocational Education. Unpublished Lecture note mimeographs of the University of Nigeria, Nsukka.

Ajayi, G.A. (1991). Strategies and Methods of Teaching Vocational and Technical Subjects at NCE level. Case study of Agricultural Science Practical. Paper presented at the National workshop on Strategies and Methods of Teaching Vocational subjects organized by NCCE, at FCE(T), Akoka from $24^{\text {th }}-27^{\text {th }}$ July.

Amadi, U.P.N. (2006). A Guided Approach for Developing Training Materials for Youth Agricultural Programmes. Interdisciplinary Journal (INTEJ) of the world Council on Curriculum and Instruction (WCCI) 2 (1).

Amadi, U.P.N. (2007). Agricultural Entrepreneurship Development: Constrains to and Initiatives for Youth employment in Nigeria. Journal of Education for Professional Growth (JEPG) 3 (1).

Amadi, U.P.N., Orikpe, E.A. \& Osinem, E.C. (2007). Theoretical Foundation of Vocational and Technical Education: Umunze: Annyco Printers and Publishers.

Bridges, D. (1993). Transferable Skills: A Philosophical Perceptive. Studies in Higher Education 18 (1).

Eccelestone, I.L. (1997). Energizing or Enervating. Journal of Vocational Education and Training 49 (1).

Elom, O. (2006). Manpower Development in Nigeria through Industrial Training. Enugu: Tinks Graphics Publishing Company.

Hodgetts, B. (1982). Effective Small Business Management. New York: Academic Press.

Holmes, L. (1995). The Capability Curriculum Conventions of Assessment and the Construction of Graduates Employability www.resil.org.uk/gradsce-ga-gi.htm Institute on Community Integration .downloaded 21/10/2011.

The WBL Approach to Productive Employment for Youth Disabilities. Icipubeumn.edu.downloaded 21/10/2011.

Jarred, R. \& Jefsioutine, M. (2006). Reflection on Using Online Contact for Work-Based Learning and Teaching in Art and Design. Art, Design and Communication in Higher Education 5 (1).

Johnson, D, Sword, C. \& Habhegger, B. (2004). Essential Tools: A Handbook for Implementing a Comprehensive WorkBased Learning Programme according to Fair Labour Standard Act $3^{r d}$ Edition: The University of Minnesota.

Mentoring Youth for Success downloaded from scorecardforkskills.com 21/10/2011.

National Centre on Secondary Education and Training (NCSET) (2005): Work-Based Learning Programme. Downloaded from scorecardforkskills.com 21/10/2011.

Okon, U.E. (2011). Work-Based Learning initiatives. Paper presented at Step-B/World Bank-assisted TVET Teachers Upskilling workshop held at the University of Nigeria, Nsukka from $23^{\text {rd }}$ October $-4^{\text {th }}$ November, 2011.

Orji, L.O. (1996). Apprenticeship Practices for skill Acquisition in Arts and craft. In Eze, T.I. \& Esomonu NPM. (eds) Implications of Vocational and Technical Education for Technological Development. A publication of Umunze FCE(T) Research and Publication Unit.

Schrenko, L.C. (2010). Standards and Guidelines for Work-Based Learning Programmes in Georgia. State of Georgia Department of Education.

Zahrandeen, U.A. (1990). Integrating Productive Work into Vocational and Technical Education in Nigeria. Technical Education Today 2 (1). 